International Journal of Biology, Pharmacy and Allied Sciences (IJBPAS) 'A Bridge Between Labottory and Qandor'

Www.ijbpas.com

\title{
EFFECT OF KSHEERBALA AVARTANA TAILA NASYA IN THE MANAGEMENT OF MANYASTMBHA W.S.R. TO CERVICAL SPONDYLOSIS- A CASE STUDY
}

\section{PATIL MS $^{1}$, PATIL DB ${ }^{2 *}$ AND CHOUDHARY I ${ }^{3}$}

1: Final Year PG Scholar, Department of Panchakarma, Parul Institute of Ayurveda

2: Associate Professor, Department of Panchakarma, Parul Institute of Ayurveda

3: MD Panchakarma, Parul Institute of Ayurveda

*Corresponding Author: Dr. Dinesh B. Patil: E Mail: dr.dineshpatil3@gmail.com

Received 12 ${ }^{\text {th }}$ Dec. 2021; Revised $14^{\text {th }}$ Jan. 2022; Accepted $7^{\text {th }}$ Feb. 2022; Available online $5^{\text {th }}$ March 2022

\section{https://doi.org/10.31032/IJBPAS/2022/11.3.1086}

\begin{abstract}
Manyastambha is one among the most common type of urdhvajatrugata Vatvyadhi found in clinical practice. It is a disorder which is prevalent in the most active period of life. It was mostly seen in old age, but now adays it is encountered in young and middle age Also people also and can be compared to cervical spondylosis of contemporary science. In Ayurveda Nasyakarma is the prime line of treatment for all Urdhwajatrugata Vikara. In this study, a diagnosed with case of Manyastambha has been included for its Ayurvedic management. A male patient 62-year-old age came with complaint of pain and stiffness in the last 6 months was treated by Ksheerbala Avartana Taila Nasya. A good relief was found in pain and stiffness. Nasya with Ksheerbala Aavartana Taila showed significant improvement in the case of Manyastambha.
\end{abstract}

Keywords: Manyastambha, Cervical Spondylosis, Nasya, Ksheerbala Aavartana Taila

\section{INTRODUCTION}

In present scenario, human life is affected by many degenerative problems because of change in life style, food habit, stress, excessive travelling, lack of exercise's are becoming part of life. These life style modifications have long term effect on healthy status of human being.

According to Acharya Sushruta, sleep in day time, leaning or sleeping on an uneven place, constantly gazing upwards lead to the disease Manyastambha ${ }^{1}$. In modern 
terminology Manyastambha can be corelated with cervical spondylosis. Cervical spondylosis is degeneration of cervical spine ${ }^{2}$.The Manyastambha is disease which causes Ruk (pain), Stambha (stiffness), restricted movements in Manya Pradesh $^{3}$.

Nasya karma is considered as the prime treatment for Urdhwajatrugata vikara ${ }^{4}$ also it is a best line of treatment for the Manyastambha ${ }^{5}$ which decreases Prakupita Vata \& Kapha Dosha. In general, for Nasya karma the Taila yoga's are more commonly used as Taila have properties which are opposite to qualities of Vata and Kapha Dosha ${ }^{6}$, for Nasya Karma we require Mrudu paka or Madhyama Paka taila yoga's and in practice we generally use Madhyama paka.

The classical dose of Snehana Nasya karma is very high which is practically not possible, so to reduce the classical dose of Snehana Nasya karam and to get desired effect from Nasya karma we can use the Avartita Taila, as it is found that Avartita Sneha Nasya is more potent and can get easily absorbed in deeper tissue.
There are many taila yoga's are told for Nasya Karma in our classics and Ksheerabala Aavartana taila which is mentioned in Sahasrayoga is used in the management of vatavyadhi ${ }^{7}$. Is one among such yoga which is routinely practiced.

\section{CASE REPORT.}

A male patient aged 62 years came to Panchakarma OPD at Parul Ayurveda Hospital, Parul University, Vadodara, Gujrat. A patient came with the complaining of Manyashoola, Stambha and Gaurava in Manyapradeshi. He was unable to move his neck due to pain and stiffness in the last 6 months.

\section{HISTORY OF PRESNT ILNESS -}

Patients was having chief complaints of Manyashool and Gaurava in the last 6 months, but from 4 months increase in severity of symptoms are noted with stambha, so he came to Parul Ayurved hospital for further treatment.

\section{PAST HISTORY}

No H/o any other major illness like DM/ TSH/ HYPERTENSION, etc., or surgical treatment.

PERSONAL HISTORY -

\begin{tabular}{|c|c|c|}
\hline Aahar hetu & Vihar hetu & Manasik hetu \\
\hline Katu, Laghu, & He works about \\
Rooksha,Tikta, & $10-12$ hours \\
Kashaya rasa & daily & \\
pradhan aahar. & & \\
2. Irregular meal \\
timing.
\end{tabular}




\section{GENERAL EAMINATION -}

1. Condition - conscious and afebrile.

2. Pulse rate $-78 / \mathrm{min}$

3. B.P.- $130 / 90$

4. R.R.- $18 / \mathrm{min}$.

5. Systemic examination.

a. R.S.- A. E= B.E- clear.

b. C.V.S.-S1S2 Normal. No abnormal sound.

c. C.N.S. - Conscious and oriented.

6. P/A: - Soft. Liver, Kidney, Spleennot palpable.

7. Prakruti: - Vata Pradhan Pitta.

8. Satva: - Avara.

9. Sara: - MAdhyam.

10. Aahar Shakti: - Madhyama

11. Vyayam Shakti: - Avara
ASHTAVIDHA PARIKSHANA-

1) Nadi - Vatapradhan pitta

2) Mala- Prakruta

3) Mutra- 2-3 times per day.

4) Jivha- Alipta

5) Shabda- Prakruta

6) Sparsha- Ushna

7) Druk- Prakruta

8) Akriti- Madhyama.

\section{CLINICAL EXAMINATION OF SPINE}

Inspection- No any abnormality was seen.

Gait- Normal

INVESTIGATION (on the day of admission)

$\mathrm{Hb}-14.5 \mathrm{gm} \%$

Urine examination - Protein - nil, Sugar-

Nil, Albumin-Nil RBCs-Nil

RBS- 97 mg/dl

X-RAY CERVICAL SPINE - (Date-21/11/2019)

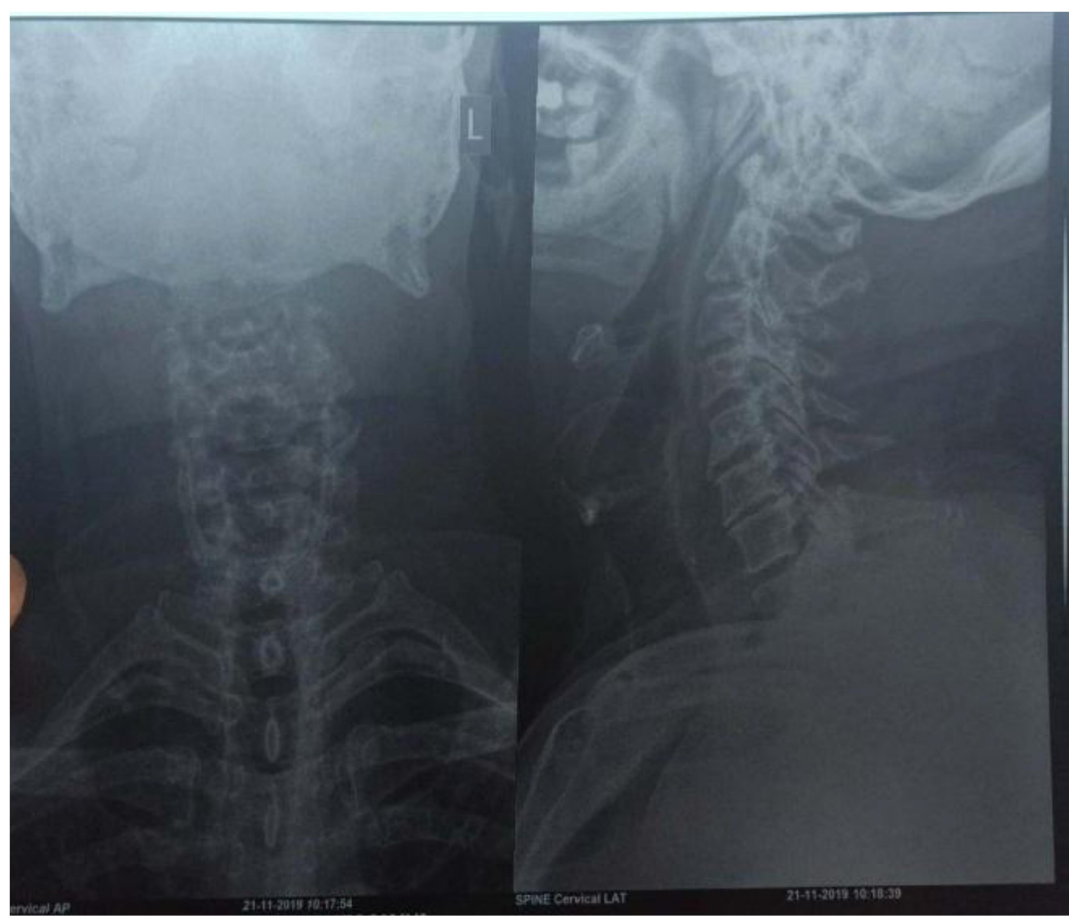


Cervical spine which reported degenerative changes with osteophytosis at $\mathrm{C} 6-\mathrm{C} 7$ and C5-C6.

\section{DIAGNOSIS AND ASSESSMENT}

Manyastmbha was dignosed by complaints like pain in neck, Stiffness and X-ray findings like osteophyte.

\section{TREATMENT-}

1) Sthanik Abhyanga with Moorchita tila taila.

2) Sthanik Bhaspa sweda

3) Sneha Nasya with Ksheerbala Aavartan Taila.

\section{INTERVENTION}

\begin{tabular}{|c|c|c|c|c|c|}
\hline Sr. no. & Date & Treatment & Medicine used & Dose & Frequency \\
\hline 1 & $\begin{array}{c}22 / 11 / 19 \text { TO } \\
28 / 11 / 19\end{array}$ & $\begin{array}{c}\text { Sthanik Abhyanga } \\
\text { with moorchita tila } \\
\text { taila \& Sthanik } \\
\text { Bhaspa Sweda } \\
\text { Sneha Nasya }\end{array}$ & $\begin{array}{c}\text { Ksheerbala } \\
\text { Aavartana } \\
\text { Taila }\end{array}$ & $\begin{array}{c}4 \text { Bindu } \\
\text { each } \\
\text { nostril for } \\
7 \text { days }\end{array}$ & Once in a day \\
\hline
\end{tabular}

\section{ASSESSMENT PARAMETERS}

1) Manyashool

2) Stambh

3) Gaurav

\section{Subjective Criteria Grading :-}

a) Manyashool (pain) by Vas analogue scale

\begin{tabular}{|c|c|}
\hline Symptoms & Grade \\
\hline No pain & 0 \\
\hline Mild pain occasionally & 1 \\
\hline More than mild but tolerable & 2 \\
\hline Severe pain continuous & 3 \\
\hline
\end{tabular}

b) Stambha (Stiffness)

\begin{tabular}{|c|c|}
\hline Symptoms(stiffness) & Grade \\
\hline Absent & 0 \\
\hline Mild occasionally & 1 \\
\hline Moderate for 30 min. to 1 hour daily & 2 \\
\hline Severe, Persistent & 3 \\
\hline
\end{tabular}

c) Gaurav (Heaviness)

\begin{tabular}{|c|c|}
\hline Symptoms & Grade \\
\hline Absent & 0 \\
\hline Mild occasionally for 10 to 30 min & 1 \\
\hline Moderate for 30 min. to 1 hour & 2 \\
\hline Severe, Persistent > hour & 3 \\
\hline
\end{tabular}

\section{Objective Criteria: -}

Range of movement of neck was measured with Goniometry.

\section{RESULT}

\section{ASSESSMENT FOR TREATMENT:}

\section{A. Subjective parameters: -}




\section{B. Objective parameters: -}

\begin{tabular}{|c|c|c|c|c|}
\hline Parameters & B.T. & A.T. & $1^{\text {st }}$ follow up & $2^{\text {nd }}$ follow up \\
\hline Flexion & 17degree & 24 degree & 35 degree & 43 degree \\
\hline Extension & 20 degree & 29 degree & 36 degree & 44 degree \\
\hline Rt. Lat. Flexion & 21 degree & 26 degree & 33 degree & 39 degree \\
\hline Lt. Lat. Flexion & 22 degree & 29 degree & 33 degree & 45 degree \\
\hline Rt. Rotation & 19 degree & 40 degree & 67 degree & 80 degree \\
\hline Lt. Rotation & 19 degree & 39 degree & 59 degree & 80 degree \\
\hline Parameters & B.T. & A.T. & $1^{\text {st }}$ follow up & $2^{\text {nd }}$ follow up \\
\hline Manyashoola & 3 & 2 & $\mathbf{0}$ & $\mathbf{0}$ \\
\hline Stambha & 2 & 1 & 1 & $\mathbf{0}$ \\
\hline Gaurav & 3 & 3 & 2 & 1 \\
\hline chimchimayana & $\mathbf{0}$ & $\mathbf{0}$ & $\mathbf{0}$ & $\mathbf{0}$ \\
\hline
\end{tabular}

\section{DISCUSSION}

Manyastambha has been described as one among the nanatmaja vyadhi cause by Vata $d o s h a^{9}$. It is mainly degenerative disease. The Nidanas (causes) the, vitiation of Vata, which in turn lodges into the Asthi Dhatu. The movement of the joints is performed by the Sleshmaka Kapha situated in the joints. Later the increased Vata diminishes this Sleshmaka Kapha, which further facilitate the Asthikshaya. i.e., degeneration of the bones, which is found in the pathogenesis of Cervical Spondylosis. The psychological factors like Shoka, Bhaya, chinta etc. lead to provocation of vata which leads to degenerative diseases. According to Acharya Vruddhi in Vata dosha related to Kshaya of Asthi dhatu and Kshaya of Vata is related to Vruddi in Asthidhatu ${ }^{10}$. In Manyastambha Asthidhatukshaya is the main factor which is due to Vatavruddhi.

Root of administration always has its own importance in management of any disease. According to Ayurvedic classics the diseases which are occurring above the neck, Nasya therapy is most favourable or important. In urdhwajatrugata vikara nasya is best treatment and it's already proved and explained by vaidhya's. Manyastambha is one among them, there is dhatukshayajanya vataprakopa in Manya Pradesh in cervical Spondylosis. Here Vata gets vitiated by Laghu, Ruksha, and Chala properties of Vata. Ksheerbala Avartana Taila decreases all above gunas with its Guru, Snigdha, Ushna gunas and pacifies Vata. And Madhura rasa and Madhura Vipaka acts as Brumhana thus ultimately Dhatukshaya was reduced. And also because of its ksheerpaki nature it acts as Balya \& Brumhana. And due to its Aavartana properties the medicament easily enters in Sukshma level within very small span of time.

The avartana changes the molecular structure of the ingredients making them more complex resulting in their increased penetration capacity at tissue level. 
Practically Aavartana Taila is more potent than normal Taila due to Agni Samskara.

\section{CONCLUSION}

In case of Manyastambha in cervical spondylosis the drugs having Vatahara, Brimhaniya and

Balya properties should be administered. The present case study shows significant remission in signs, and symptoms of Manyastambha. Nasya karma is having prolonged action.

\section{REFERENCES-}

[1] Susrut Samhita of Maharsi-Susruta edited with Ayurveda TattavaSandipika by Kaviraj Ambikadatta Shastri, Part-1, PublisherChaukhambha Sanskrit Sansthana, ISBN-978-81-89798-19-2, Edition Reprint-2014, Chapter-1,pg no.303.

[2] Siddhartha.N.Shah. API Text book of Medicine 29th Chapter 7th edition 2003, pg.no.885.

[3] A text book of Kayachikitsa, Volume-3 by Dr. P.S.Byadgi, Dr. A.K.Pandey., Publisher- Chaukhambha Publication, Edition Reprint-2016, ISBN-978-9381608-56-2, Chapter-1, pg.no.74.

[4] Prof. K.R.Srikantha Murthy, Edited AstangaHrudaya Sutrasthan, Volume1, Publisher- Chaukhambha Krishndas Academy, Varanasi. Reprint-1996, Chapter-20, pg.no.-255

[5] Susrut Samhita of Maharsi-Susruta edited with Ayurveda TattavaSandipika by Kaviraj Ambikadatta
Shastri, Part-1, Publisher-

Chaukhambha Sanskrit Sansthana, ISBN-978-81-89798-19-2, Edition Reprint-2014, Chapter-5,pg no.43.

[6] Charak Samhita by P.V.Sharma, Publisher- Chaukhambha Orientalia, Fourth Edition-1998. ISBN-81-7637011-8, Chapter-27,Shlok no.286.

[7] Sahasrayogam Text with English Translation, By Dr.K.Nishteswar \& Dr.R.Vidyanath, PublisherChaukhambha Sanskrit series office Varanasi, Edition-Fourth, Year 2014, ISBN-978-81-7080-172-9, Taila Prakarana, pg.no. 111.

[8] Evaluation of the efficacy of Mashadi Tail Nasya in the Management of Manystambha W.S.R. Cervical Spondylosis by Vd. Sachin Pandurang Kale. ISSN:23205091.

[9] Prof. K.R.Srikantha Murthy, Edited AstangaHrudaya Nidanasthan, Volume-1, Publisher- Chaukhambha Krishndas Academy, Varanasi. Reprint-1996, Chapter-15, pg.no.-152.

[10] Prof. K.R.Srikantha Murthy, Edited AstangaHrudaya Sutrasthan, Volume1, Publisher- Chaukhambha Krishndas Academy, Varanasi. Reprint-1996, Chapter-11, Shlok no. 27 . 